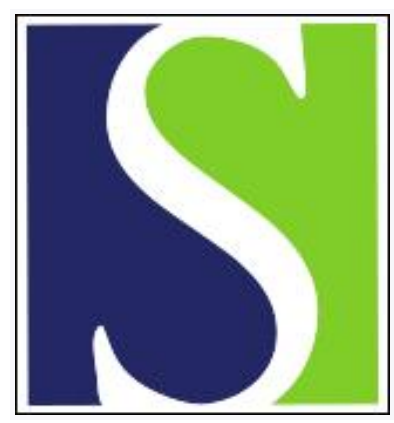

Scand J Work Environ Health 2007;33(4):252-259

https://doi.org/10.5271/sjweh.1140

Issue date: 31 Aug 2007

Job stress and depression symptoms in middle-aged workers-prospective results from the Belstress study

by Clays E, De Bacquer D, Leynen F, Kornitzer M, Kittel F, De Backer G

Affiliation: Department of Public Health, Ghent University, University Hospital-(2) Block A, De Pintelaan, 185, B-9000 Ghent, Belgium. els.clays@UGent.be

Refers to the following texts of the Journal: 1996;22(2):139-145

2001;27(2):146-153 1997;23(5):334-341 2006;32(6):443-462

2002;28(2):94-108

The following articles refer to this text: 2015;41(3):299-311;

2015;41(3):312-321; 2018;44(2):183-191

Key terms: Belstress study; depression symptom; job stress; longitudinal study; mental health; middle-aged worker; strain; work; work stress

This article in PubMed: www.ncbi.nlm.nih.gov/pubmed/17717616 


\title{
Job stress and depression symptoms in middle-aged workers-prospective results from the Belstress study
}

\author{
by Els Clays, MSc, ${ }^{1}$ Dirk De Bacquer, PhD, ${ }^{1}$ Francoise Leynen, MD, ${ }^{2}$ Marcel Kornitzer, PhD, ${ }^{2}$ France Kittel, \\ $P h D,{ }^{2}$ Guy De Backer, PhD ${ }^{1}$
}

Clays E, De Bacquer D, Leynen F, Kornitzer M, Kittel F, De Backer G. Job stress and depression symptoms in middleaged workers - prospective results from the Belstress study. Scand J Work Environ Health 2007;33(4):252-259.

\begin{abstract}
Objective The aim of this study was to explore the prospective relation between job stress and symptoms of depression within a cohort study.

Methods Altogether 2821 workers were involved in the longitudinal Belstress study (Belgian job stress study); there were two measurements with a mean follow-up time of 6.6 years. Job stress was assessed by the Job Content Questionnaire. Depression symptoms were assessed by the Iowa form of the Center for Epidemiological Studies-Depression Scale. Baseline and repeated exposures to job stress were related to the development of high levels of depression symptoms through logistic regression analysis.

Results Within a population free of high depression scores at baseline, job stress increased the risk of developing high levels of depression symptoms after a mean follow-up time of 6.6 years. Independent associations were found for low decision latitude, high job strain, and isolated strain among women, but not among men. The adjusted association with high job strain among men was borderline significant. Repeated high job strain was associated with a more elevated risk of developing high levels of depression symptoms among both the women and the men.

Conclusions The results of this study confirm that job stress is a risk factor for developing symptoms of depression. Stronger associations were found for women. The impact of high job strain among both men and women was more harmful when there was repeated exposure.
\end{abstract}

Key terms longitudinal study; mental health; strain; work.

There is general agreement about the multifactorial etiology of mental health disorders. Affective disorders are believed to be psychosocial in nature, with a complex interweaving of both social and psychological characteristics (1). During the last decennia, more and more attention has been given to the role of the work environment in determining people's mental health condition. According to the Third European Survey on Working Conditions conducted in 2000, most European workers believe that their work affects their health (2). Psychological distress represents a substantial part of these work-related health problems (2).
The most influential and widely used model in occupational health research is the demand-control-support model developed by Karasek in the 1970s (3-5). According to this model, adverse health effects are expected when workers are exposed to high psychological demands in combination with low decision latitude or job control, which is labeled "high job strain". The "isostrain" hypothesis states that people with high strain and low social support at work, labeled "isolated strain", are the most vulnerable to negative health effects.

In general, results on job strain and psychological well-being are not consistent across studies (6). Support

1 Department of Public Health, Ghent University, University Hospital, Ghent, Belgium.

2 Laboratory of Epidemiology and Health Promotion, School of Public Health, Free University of Brussels, Brussels, Belgium.

Correspondence to: Els Clays, Department of Public Health, Ghent University, University Hospital—(2) Block A, De Pintelaan, 185, B-9000 Ghent, Belgium. [E-mail: els.clays@UGent.be] 
for an association is mainly found in cross-sectional studies, while longitudinal studies are rather scarce and provide less support. In several cross-sectional studies, adverse work conditions have been found to be related to poor mental health outcomes $(3,7-21)$. These studies, however, cannot give an indication regarding the causal nature of the relation.

As far as longitudinal studies are concerned, prospective associations between job stressors and adverse mental health conditions were found in some studies with rather small sample sizes (22-26) and in a few large-scale studies $(27,28)$, while negative results were reported in one study (29). Within the Whitehall II study comprising more than 7000 participants, work characteristics predicted several mental health outcomes (30-33). A meta-analysis of 11 longitudinal studies provided evidence that the psychosocial work environment is a prospective risk factor for common mental disorders (34). Results in prospective studies are usually based on a single assessment of job stressors. Only a few studies examined multiple measurements of job stressors and found cumulative exposure of job stressors to be an important predictor of mental health indicators (35-37).

Within the first phase of our Belstress study (Belgian job stress study), including more than 21000 middleaged workers, several aspects of psychological well-being were cross-sectionally associated with job stress according to the demand-control-support model $(38,39)$. In the longitudinal part of the Belstress study, we wanted to explore the prospective relation between job stress and depression symptoms within a cohort study. The first objective was to describe prospectively the impact of job stress according to the demand-control-support model on the development of depression symptoms. The second objective was to relate repeated exposure to job strain with depression symptoms. We hypothesized that the impact of job strain on depression symptoms is even more harmful when there is consistent exposure measurement.

\section{Study population and methods}

\section{Study population}

The association between job stress and depression symptoms was assessed using data from the Belstress study, an epidemiologic cohort study about job stress, cardiovascular and other health issues, and sick leave $(40,41)$. Altogether 2821 workers from nine companies or public administrations were involved in the longitudinal part of the study. All of the workers aged 35-59 years within the companies were invited to participate. Data were gathered at baseline between 1995 and 1998 (time 1) and a second time in 2002-2003 (time 2) after a mean follow-up time of 6.6 (SD 1.13, range 4) years. A participation rate of $67.2 \%$ was reached during the second phase. The population contained 1950 men and 871 women aged 35-59 years at the beginning of the study. These workers were employed within two public administrations (55\% of the sample), six private companies (34\%), and one bank (11\%). The sample included 500 executives (18\%), 1291 white-collar workers (46\%), and 997 blue-collar workers (36\%). The baseline characteristics of the study population are presented in table 1 .

The Belstress study was approved by the ethics committees of the University Hospital of Ghent and the Faculty of Medicine of the Free University of Brussels.

\section{Data collection}

At both time 1 and time 2, the participants completed a self-administered questionnaire. Job stress was assessed using the standardized Job Content Questionnaire, based on Karasek's demand-control-support model (42). Psychological job demands were composed of the sum score (range 5-20) of five items that related to mental work load, organization constraints on task completion, and conflicting demands (eg, "My job requires working very hard" and "I have enough time to get the job done"). Job control or decision latitude was composed of the sum score (range 9-36) of two subscales: "skill discretion" or the level of skill and creativity required on the job (sum score of six items, eg, "My job requires a high skill level" and "My job requires that I learn new things") and "decision authority" or the possibilities for workers to make decisions about their work (sum score of three items, eg, "My job allows me to make a lot of decisions

Table 1. Characteristics of the study population at baseline $(\mathrm{N}=2821)$.

\begin{tabular}{lcccccc}
\hline Characteristic & \multicolumn{2}{c}{$\begin{array}{c}\text { Men } \\
(\mathrm{N}=1950)^{\mathrm{a}}\end{array}$} & & \multicolumn{3}{c}{$\begin{array}{c}\text { Women } \\
(\mathrm{N}=871)^{\mathrm{b}}\end{array}$} \\
\cline { 2 - 3 } \cline { 6 - 7 } & $\mathrm{N}$ & $\%$ & & $\mathrm{~N}$ & $\%$ \\
\hline Educational level & & & & & \\
Low & 739 & 37.9 & & 320 & 36.7 \\
Medium & 554 & 28.4 & & 330 & 37.9 \\
High & 638 & 32.7 & & 214 & 24.6 \\
Low social network & 929 & 47.6 & & 489 & 56.1 \\
Low satisfaction with private life & 135 & 6.9 & & 105 & 12.1 \\
External locus of control & 533 & 27.3 & & 225 & 25.8 \\
High level of depression symptoms & 390 & 20.0 & & 309 & 35.5 \\
High job demands & 923 & 47.3 & & 351 & 40.3 \\
Low decision latitude & 782 & 40.1 & & 529 & 60.7 \\
High job strain & 300 & 15.4 & & 196 & 22.5 \\
Low social support & 823 & 42.2 & & 360 & 41.3 \\
Isolated strain & 190 & 9.7 & & 107 & 12.3 \\
\hline
\end{tabular}

a Mean age 43.7 (SD 5.0) years.

${ }^{b}$ Mean age 42.8 (SD 5.0) years. 
on my own" and "I have a lot of say about what happens in my job"). The third dimension of social support at the workplace also consisted of the sum score (range 8-32) of two subscales: "supervisor support" (sum score of four items, eg, "My supervisor pays attention to what I am doing" and "My supervisor is helpful in getting the job done") and "co-worker support" (sum score of four items, eg, "People I work with take a personal interest in me" and "People I work with are friendly"). All of the questionnaire items had four response categories (1-4, with 1 "fully disagree" and 4 "fully agree"). The Job Content Questionnaire has proved to be a valid and reliable tool with which to measure job stressors (4); its validity and reliability were also confirmed within the first Belstress study (43). Dichotomous variables (low versus high) were created for demands, control, and support on the basis of the median values (12 for demands, 27 for control, and 23 for support). High job strain referred to the combination of high job demands and low decision latitude. Isostrain or isolated strain was defined as high job strain combined with low social support. These categories were compared with all of the other possible combinations in order to test the (iso-)strain hypothesis of the model.

The Center for Epidemiological Studies-Depression Scale is a standardized tool for measuring symptoms of depression (44). In this study, we used the shorter Iowa form with 11 items, whose reliability and validity has been shown $(45,46)$. Example items are "I felt depressed during the last two weeks" and "I felt lonely during the last two weeks". The items had three response categories (1-3, with 1 "rarely or never", 2 "sometimes", and 3 "most of the time"). Symptoms of depression were calculated as the sum score of the 11 items (range 11-33). In the original 20-item Center for Epidemiological Studies-Depression Scale, a cut point of 16 is commonly used to indicate a high level of depression symptoms; this cut-point corresponds to the 80th percentile of scores attained in community samples (45, 46). Therefore, we chose to consider those with scores of 19 or higher as reporting high levels of depression symptoms, corresponding to the 80th percentile in our sample.

Information was gathered on possible confounding variables. To begin with, we wanted to take some essential sociodemographic factors into account; the baseline questionnaire provided data concerning age (35-44 years or 45-59 years) and educational level (low, medium, or high). In addition, we included social network (low or high) and satisfaction with private life (low or high) in the analyses because several studies have shown the importance of private life factors next to work characteristics in relation to mental health $(33,47)$. Finally, the personality factor locus of control has also been found to be associated with psychological well-being, and it was controlled in our analyses $(48,49)$. Two items ("I can do little to change important things in my life" and the reversed item "What happens in the future depends largely on myself") with four response categories (1-4, with 1 "fully disagree" and 4 "fully agree") were included to measure locus of control (sum score, range 2-8). The respondents with scores of six or higher were considered to have an external locus of control. These are people who believe they have no or little power to change things in their lives or to determine what will happen in the future. Low education was defined as primary school level only; high education as high school or university. The strength of social networks referred to a score based on three items regarding the number and nature of contacts with friends and family (50). A high or strong social network was attributed when the participants had regular contacts (at least once a month) with at least five close friends or family members. One question was added that asked about general satisfaction with private life ("How satisfied are you with your private life?"). Low satisfaction referred to being (very) dissatisfied as opposed to neutral or (very) satisfied.

\section{Statistical analyses}

Job stress at baseline was related to depression symptoms after a mean follow-up time of 6.6 years. For these prospective analyses, the participants with high depression symptoms at baseline were excluded. We excluded cases with high levels of depression symptoms (scores of 19 or higher) and cases with a missing value for this variable at baseline, resulting in a population of 2139 participants.

Chi-square tests were performed to explore whether job stress and the possible confounding variables at baseline were univariately associated with depression symptoms at time 2 . The independent impact of job stress on depression symptoms was assessed in a multivariate logistic regression analysis. All of the variables were entered in a single step. Adjustments were made for age, educational level, social network, satisfaction with private life, and locus of control, regardless of the results of their univariate associations with the outcome variable (51). [This was done to avoid incorrect rejection of potentially important variables.] We also controlled for the time-1 score of depression symptoms. The interaction effects were assessed between job demands and job control and between job strain and social support in relation to depression symptoms.

Repeated high job strain and repeated isolated strain were related to depression symptoms at time 2 through a logistic regression analysis. The following four groups were created: (i) those with high job strain or isolated strain at both observation times, (ii) those not exposed to high job strain or isolated strain at either observation, 
(iii) those with high job strain or isolated strain only at time 1, and (iv) those with high job strain or isolated strain only at time 2 .

Analyses were performed separately for the men and women because associations between work factors and psychological well-being have generally shown to be unequal for the genders $(6,34)$. All of the analyses were conducted using SPSS 12.0 software (SPSS Inc, Chicago, IL, USA).

\section{Results}

Sample characteristics at baseline are shown in table 1 on page 253. The mean baseline values were 15.4

Table 2. Univariate associations between the baseline characteristics and depression symptoms at time $2(\mathrm{~N}=2139)$.

\begin{tabular}{|c|c|c|c|c|c|c|c|c|}
\hline \multirow{3}{*}{$\begin{array}{l}\text { Baseline } \\
\text { characteristic }\end{array}$} & \multicolumn{8}{|c|}{ High level of depression symptoms at time 2} \\
\hline & \multicolumn{4}{|c|}{ Men $(N=1568)$} & \multicolumn{4}{|c|}{ Women $(\mathrm{N}=571)$} \\
\hline & $\mathrm{N}$ & $\%$ & $\begin{array}{l}\text { Chi- } \\
\text { square }\end{array}$ & $\begin{array}{l}\mathrm{P}- \\
\text { value }\end{array}$ & N & $\%$ & $\begin{array}{l}\text { Chi- } \\
\text { square }\end{array}$ & $\begin{array}{c}\mathrm{P}- \\
\text { value }\end{array}$ \\
\hline Job demands & & & $4.31^{\mathrm{a}}$ & 0.04 & & & $1.18^{\mathrm{a}}$ & 0.28 \\
\hline $\begin{array}{l}\text { Low } \\
\text { High }\end{array}$ & $\begin{array}{l}60 \\
78\end{array}$ & $\begin{array}{r}7.6 \\
10.6\end{array}$ & & & $\begin{array}{l}62 \\
48\end{array}$ & $\begin{array}{l}19.1 \\
23.0\end{array}$ & & \\
\hline Decision latitud & & & $2.40^{\mathrm{a}}$ & 0.12 & & & $10.98^{a}$ & 0.00 \\
\hline $\begin{array}{l}\text { Low } \\
\text { High }\end{array}$ & $\begin{array}{l}60 \\
78\end{array}$ & $\begin{array}{r}10.5 \\
8.2\end{array}$ & & & $\begin{array}{l}84 \\
29\end{array}$ & $\begin{array}{l}25.8 \\
13.8\end{array}$ & & \\
\hline High job strain & & & $11.72^{\mathrm{a}}$ & 0.00 & & & $7.89^{\mathrm{a}}$ & 0.01 \\
\hline $\begin{array}{l}\text { No } \\
\text { Yes }\end{array}$ & $\begin{array}{r}105 \\
32\end{array}$ & $\begin{array}{r}8.0 \\
15.3\end{array}$ & & & $\begin{array}{l}76 \\
34\end{array}$ & $\begin{array}{l}18.4 \\
30.6\end{array}$ & & \\
\hline Social support & & & $7.54^{\mathrm{a}}$ & 0.01 & & & $3.00^{\mathrm{a}}$ & 0.08 \\
\hline $\begin{array}{l}\text { Low } \\
\text { High }\end{array}$ & $\begin{array}{l}70 \\
66\end{array}$ & $\begin{array}{r}11.6 \\
7.4\end{array}$ & & & $\begin{array}{l}51 \\
56\end{array}$ & $\begin{array}{l}24.6 \\
18.3\end{array}$ & & \\
\hline Isolated strain & & & $10.42^{\mathrm{a}}$ & 0.00 & & & $14.45^{\mathrm{a}}$ & 0.00 \\
\hline $\begin{array}{l}\text { No } \\
\text { Yes }\end{array}$ & $\begin{array}{r}117 \\
21\end{array}$ & $\begin{array}{r}8.4 \\
17.1\end{array}$ & & & $\begin{array}{l}87 \\
24\end{array}$ & $\begin{array}{l}18.7 \\
40.0\end{array}$ & & \\
\hline Age & & & $0.64^{\mathrm{a}}$ & 0.43 & & & $0.02^{a}$ & 0.88 \\
\hline $\begin{array}{l}35-44 \text { years } \\
45-59 \text { years }\end{array}$ & $\begin{array}{l}69 \\
70\end{array}$ & $\begin{array}{l}8.5 \\
9.7\end{array}$ & & & $\begin{array}{l}75 \\
38\end{array}$ & $\begin{array}{l}20.4 \\
21.0\end{array}$ & & \\
\hline Educational lev & & & $0.68^{b}$ & 0.71 & & & $1.40^{\mathrm{b}}$ & 0.50 \\
\hline $\begin{array}{l}\text { Low } \\
\text { Medium } \\
\text { High }\end{array}$ & $\begin{array}{l}54 \\
39 \\
45\end{array}$ & $\begin{array}{l}9.8 \\
8.7 \\
8.4\end{array}$ & & & $\begin{array}{l}42 \\
44 \\
26\end{array}$ & $\begin{array}{l}23.0 \\
20.3 \\
17.7\end{array}$ & & \\
\hline Social network & & & $5.61^{\text {a }}$ & 0.02 & & & $0.11^{\mathrm{a}}$ & 0.74 \\
\hline $\begin{array}{l}\text { Low } \\
\text { High }\end{array}$ & $\begin{array}{l}73 \\
54\end{array}$ & $\begin{array}{r}10.6 \\
7.1\end{array}$ & & & $\begin{array}{l}58 \\
45\end{array}$ & $\begin{array}{l}20.5 \\
19.3\end{array}$ & & \\
\hline Satisfaction wit & th priv & ate life & $11.70^{a}$ & 0.00 & & & $4.89^{a}$ & 0.03 \\
\hline $\begin{array}{l}\text { Low } \\
\text { High }\end{array}$ & $\begin{array}{r}12 \\
126\end{array}$ & $\begin{array}{r}22.2 \\
8.6\end{array}$ & & & $\begin{array}{l}12 \\
99\end{array}$ & $\begin{array}{l}35.3 \\
19.5\end{array}$ & & \\
\hline Locus of contro & & & $18.69^{a}$ & 0.00 & & & $0.17^{\mathrm{a}}$ & 0.68 \\
\hline $\begin{array}{l}\text { Internal } \\
\text { External }\end{array}$ & $\begin{array}{l}79 \\
58\end{array}$ & $\begin{array}{r}7.2 \\
14.5\end{array}$ & & & $\begin{array}{l}76 \\
26\end{array}$ & $\begin{array}{l}19.6 \\
21.3\end{array}$ & & \\
\hline
\end{tabular}

a Degree of freedom: 1 .

b Degrees of freedom: 2.
(SD 4.0) for depression symptoms, 12.7 (SD 2.6) for job demands, 25.8 (SD 4.5) for decision latitude, and 22.6 (SD 3.6) for social support.

Within the sample of 2139 workers free of high levels of depression symptoms at baseline, 252 cases $(11.8 \%)$ with high levels of depression symptoms were identified at time 2 . This proportion of newly developed depression symptoms was significantly higher for the women than for the men: 113 of 571 women $(19.8 \%)$ and 139 of 1568 men $(8.9 \%)(\mathrm{P}<0.001)$. Several job stress and confounding variables were associated at baseline with time-2 depression symptoms (table 2). The men and women in the groups with high job strain and isolated strain developed significantly more depression symptoms at time 2 than the others. Depression symptoms were significantly associated with low decision latitude among the women and with high job demands and low social support among the men. Significant associations were also found with low satisfaction with private life, small social network, and external locus of control among the men.

The independent impact of job stress on depression symptoms was assessed in a multivariate logistic regression analysis (table 3 ). Among the women, high levels of time-2 depression symptoms were significantly associated with time-1 low decision latitude. High job strain increased the risk for depression symptoms; this association was significant for the women and borderline significant for the men $(\mathrm{P}=0.06)$. Among the women, the risk was more than doubled by isolated strain.

Table 3. Adjusted associations between baseline job stress and depression symptoms at time $2(\mathrm{~N}=2139)$. (OR = odds ratio, 95\% $\mathrm{Cl}=95 \%$ confidence interval)

\begin{tabular}{|c|c|c|c|c|}
\hline \multirow[t]{3}{*}{ Baseline job stress } & \multicolumn{4}{|c|}{ High level of depression symptoms at time 2} \\
\hline & \multicolumn{2}{|c|}{ Men $(N=1568)$} & \multicolumn{2}{|c|}{ Women $(\mathrm{N}=571)$} \\
\hline & $O R^{a}$ & $95 \% \mathrm{Cl}$ & $\mathrm{OR}^{\mathrm{a}}$ & $95 \% \mathrm{Cl}$ \\
\hline \multicolumn{5}{|l|}{ Job demands } \\
\hline Low & 1 & & 1 & \\
\hline High & 1.31 & $0.87-1.99$ & 1.18 & $0.72-1.94$ \\
\hline \multicolumn{5}{|l|}{ Decision latitude } \\
\hline High & 1 & & 1 & \\
\hline Low & 1.07 & $0.71-1.62$ & 1.90 & $1.08-3.33$ \\
\hline \multicolumn{5}{|l|}{ High job strain } \\
\hline No & 1 & & 1 & \\
\hline Yes & 1.58 & $0.98-2.54$ & 1.74 & $1.00-3.01$ \\
\hline \multicolumn{5}{|l|}{ Social support } \\
\hline High & 1 & & 1 & \\
\hline Low & 1.03 & $0.69-1.54$ & 1.35 & $0.82-2.23$ \\
\hline \multicolumn{5}{|l|}{ Isolated strain } \\
\hline No & 1 & & 1 & \\
\hline Yes & 1.52 & $0.86-2.67$ & 2.53 & $1.32-4.86$ \\
\hline
\end{tabular}

a Adjusted for age, educational level, social network, satisfaction with private life, locus of control, and the score for depression symptoms at time 1. 
Table 4. Adjusted associations between repeated high job strain or isolated strain and depression symptoms at time $2(\mathrm{~N}=2139)$. (OR $=$ odds ratio, $95 \% \mathrm{Cl}=95 \%$ confidence interval)

\begin{tabular}{|c|c|c|c|c|}
\hline & \multicolumn{4}{|c|}{ High level of depression symptoms at time 2} \\
\hline & \multicolumn{2}{|c|}{ Men $(N=1568)$} & \multicolumn{2}{|c|}{ Women $(\mathrm{N}=571)$} \\
\hline & $O \mathrm{R}^{\mathrm{a}}$ & $95 \% \mathrm{Cl}$ & $\mathrm{OR}^{\mathrm{a}}$ & $95 \% \mathrm{Cl}$ \\
\hline \multicolumn{5}{|c|}{ Repeated high job strain ${ }^{b}$} \\
\hline No-no $(74.5 \%)$ & 1 & & 1 & \\
\hline Yes-no (10.3\%) & 1.25 & $0.67-2.34$ & 1.50 & $0.73-3.07$ \\
\hline No-yes $(10.0 \%)$ & 2.13 & $1.16-3.93$ & 2.14 & $1.07-4.31$ \\
\hline Yes-yes $(5.2 \%)$ & 3.31 & $1.67-6.56$ & 3.40 & $1.45-7.94$ \\
\hline \multicolumn{5}{|c|}{ Repeated isolated strain ${ }^{b}$} \\
\hline No-no $(84.8 \%)$ & 1 & & 1 & \\
\hline Yes-no (6.8\%) & 1.07 & $0.52-2.20$ & 3.16 & $1.47-6.78$ \\
\hline No-yes $(6.5 \%)$ & 3.14 & $1.67-5.90$ & 3.04 & $1.35-6.82$ \\
\hline Yes-yes $(1.9 \%)$ & 5.80 & $2.12-15.85$ & 2.12 & $0.54-8.31$ \\
\hline
\end{tabular}

a Adjusted for age, educational level, social network, satisfaction with private life, locus of control, and the score for depression symptoms at time 1.

b Percentage of the total population in parentheses.

None of the interaction terms between demands and control and between strain and support in relation to depression symptoms were significant.

The results for repeated high job strain and repeated isolated strain in relation to time 2 depression symptoms are shown in table 4 . The men and women with repeated high job strain had the highest incidence of depression symptoms when they were compared with those not in the high-strain group at either time 1 or time 2 . Those with unstable measurements showed intermediate levels of risk. The same pattern was found for repeated isolated strain among the men, but not among the women.

\section{Discussion}

The aim of this cohort study was to explore the prospective relation between job stress and depression symptoms. Within a population of 2139 middle-aged workers free of high levels of depression symptoms at baseline, job stress increased the risk of developing high levels of depression symptoms after a mean follow-up time of 6.6 years. Significant independent associations were found for low decision latitude, high job strain, and isolated strain among the women. For the men, the association with high job strain was borderline significant. This finding generally confirms results from longitudinal studies in which work factors were causally related to well-being (52). Our results are in line with findings from a few large-scale prospective studies, the Whitehall II and the Gazel study, in which job stressors, according to the demand-control-support model, were related to mental health $(28,30-32)$. The main hypotheses of the demand-control-support model were confirmed for the women; high job strain and isolated strain increased the risk of developing depression symptoms. None of the interaction terms for demands by control and for strain by support in relation to depression symptoms were statistically significant; this finding is in line with the results of a large number of studies $(6-11,13,14$, $16,20,28,29,32,38,39,52)$. A recent meta-analysis of 11 prospective studies on common mental disorders provided consistent robust evidence for causal effects for high job strain, while demands, control, and support were associated with moderate risk (34). Our findings are in line with these results, although a significant independent association was also found for low decision latitude among women.

Prospective studies in research dealing with stress and health usually base their results on a single assessment of job stress. However, measuring job characteristics at only one point in time increases the risk of misclassification due to inaccuracy in assessment (53). Only a few studies have examined multiple measurements of job stressors in relation to mental health. In a 2-year study including 1378 nurses, cumulative exposure to job strain was associated with the highest level of psychological distress (35). SMASH, a four-phase prospective cohort study with observations concerning 1477 employees, concluded that workers in the stable highstrain group reported the highest level of depression (36). The Somstress study, which used a repeated measure to assess 1986 workers at a 1-year interval, found that employees with repeated effort-reward imbalance were at the highest risk of developing poor mental health (37). Our results with repeated measures in a long-term perspective confirm that men and women with repeated high job strain and men with repeated isolated strain have the highest incidence of depression symptoms. Because of the small number of observations, it is difficult to draw conclusions about repeated isolated strain and depression symptoms among women; only three women from the group with repeated isolated strain reported high levels of depression symptoms. The impact of high job strain on depression symptoms was considerably larger when the exposure was repeated than when only baseline exposure was taken into account. Thus, on the basis of these results, we highly recommend the use of multiple measurements of job stressors. Multiple measurements result in a more reliable assessment and may help to avoid large underestimations of true associations. A similar conclusion was drawn regarding single versus consistent exposure measures of job strain in relation to coronary heart disease in the Whitehall II study (54).

Unfortunately, no information on possible changes in job stress during the time lag between the two measurements was available in this study. First, there is 
the possibility of changes in job stress due to objective changes in job title. Additional analysis (data not shown, but available from the first author) after the exclusion of the participants whose job title changed between time 1 and time 2 engendered very similar results. On the other hand, psychosocial work characteristics may have altered within the same job title. As a result, our findings regarding the impact of repeated job strain may have been underestimated. In addition, some of the confounding variables may also have changed between the two measurements.

Both job stress and depression symptoms were assessed by means of self-report measures. It is commonly assumed that relationships between variables measured with the same method, usually self-reports, are inflated due to common method variance. However, Spector (55) recently suggested that the automatic criticism of selfreports, along with the postulation that method alone is sufficient to produce biases, has become an urban legend. Based on empirical evidence, features such as social desirability should not be considered general or automatic sources of common method variance when self-reports are used. Furthermore, subjectivity bias in self-report measures was reduced by the use of validated and standardized scales for the assessment of job stress (4) and mental health $(45,46)$ in this study.

A fundamental strength of our study was its prospective design, which considerably increased the probability of a causal relation between job stress and depression symptoms. By excluding the participants with high levels of depression symptoms at baseline, and furthermore adjusting for the time-1 score for depression symptoms, an appropriate prospective design was assured. It should be noted, however, that we cannot exclude the possibility that some of the employees with low or intermediate levels of depression symptoms at baseline may have had higher scores in the past, and such a past may have influenced their perception of job stress at time 1 .

Another methodological issue is the proper adjustment for confounding variables. The relationships in our study were controlled for the essential individual and sociodemographic factors of age and educational level. Some studies have emphasized the importance of integrating factors from the private family sphere in addition to work characteristics $(33,47)$. Social network and satisfaction with private life were included in our analyses. It has been suggested that personality factors such as negative affectivity or neuroticism may confound the association between work stressors and mental health (56). Unfortunately, this kind of information was not available in our study. However, when these variables were controlled in prospective studies, occupational stressors generally remained as independent predictors of mental health indicators $(32,56)$. Locus of control has also been found to be associated with psychological well-being and with the relation between stressors and mental health $(48,49)$. This variable was controlled in our analysis.

A notable limitation is the presence of a selection bias in our population. Only the workers who were involved in both time 1 and time 2 measurements were included. Within the nine participating companies, 8783 employees participated in the first round of data collection. At time 2, more than half of the original sample was no longer eligible due to regular or premature retirement, resignation, dismissal, or death. Some companies had undergone major reorganization with subsequent discharges, as a result of which the population of possible participants had been reduced considerably. This process resulted in a healthy-worker effect; the "dropout" population perceived significantly less decision latitude and included more workers with high strain at baseline. Consequently, it is possible that the impact of job stress on mental health in this study was underestimated. In terms of baseline depression symptoms, there was no difference between the "dropout" population and the others. Within the sample of eligible workers, an acceptable participation rate of $67.2 \%$ was reached.

In conclusion, the results of this study confirm that job stress is an independent risk factor for depression symptoms. Stronger associations were found for women. Repeated high job strain was associated with more elevated risk of developing high levels of depression symptoms among both women and men. The role of work and employment in affecting mental health is still not fully understood or properly managed in relation to the protection and promotion of good mental health in Europe (57). There is need for increased interest and research in the area of occupational mental health. The main strengths of this study were its prospective design enabling the proper control of the depression outcome at baseline and the assessment of the impact of not only baseline, but also repeated job strain.

\section{Acknowledgments}

The Belstress study was funded by the Belgian Federal Public Service Employment, Labor and Social Dialogue, and by the European Social Fund.

\section{References}

1. Harris T. Recent developments in understanding the psychosocial aspects of depression. Br Med Bull. 2001;57:17-32.

2. Paoli P, Merllié D. European Foundation for the Improvement of Living and Working Conditions-Third European survey on working conditions. Luxemburg: Office for Official Publica- 
tions of the European Communities; 2000.

3. Karasek R. Job demands, job decision latitude, and mental strain: implications for job redesign. Adm Sci Q. 1979;24:285309.

4. Karasek R, Brisson C, Kawakami N, Houtman I, Bongers P, Amick B. The Job Content Questionnaire (JCQ): an instrument for internationally comparative assessments of psychosocial job characteristics. J Occup Health Psychol. 1998;3:322-55.

5. Johnson J, Hall E. Job strain, work place social support, and cardiovascular-disease- a cross-sectional study of a random sample of the Swedish working population. Am J Public Health. 1988;78:1336-42.

6. Van Der Doef M, Maes S. The job demand-control(-support) model and psychological well-being: a review of 20 years of empirical research. Work Stress. 1999;13:87-114.

7. Landsbergis P. Occupational stress among health-care workers-a test of the Job Demands-Control Model. J Organ Behav. 1988;9:217-39.

8. Stansfeld S, North F, White I, Marmot M. Work Characteristics and psychiatric-disorder in civil-servants in London. J Epidemiol Community Health. 1995;49:48-53.

9. Bourbonnais R, Brisson C, Moisan J, Vézina M. Job strain and psychological distress in white-collar workers. Scand J Work Environ Health. 1996;22(2):139-45.

10. Bourbonnais R, Comeau M, Vezina M, Dion G. Job strain, psychological distress, and burnout in nurses. Am J Ind Med. 1998;34:20-8.

11. Moisan J, Bourbonnais R, Brisson C, Gaudet M, Vezina M, Vinet A, et al. Job strain and psychotropic drug use among white-collar workers. Work Stress. 1999;13:289-98.

12. Mausner-Dorsch H, Eaton W. Psychosocial work environment and depression: epidemiologic assessment of the demand-control model. Am J Public Health. 2000;90:1765-70.

13. De Jonge J, Reuvers M, Houtman I, Bongers P, Kompier M. Linear and nonlinear relations between psychosocial job characteristics, subjective outcomes, and sickness absence: baseline results from SMASH: study on musculoskeletal disorders, absenteeism, stress, and health. J Occup Health Psychol. 2000;5:256-68.

14. Vermeulen M, Mustard C. Gender differences in job strain, social support at work, and psychological distress. J Occup Health Psychol. 2000;5:428-40.

15. Calnan M, Wainwright D, Almond S. Job strain, effort-reward imbalance and mental distress: a study of occupations in general medical practice. Work Stress. 2000;14:297-311.

16. Wang J, Patten S. Perceived work stress and major depression in the Canadian employed population, 20-49 years old. J Occup Health Psychol. 2001;6:283-9.

17. Tsutsumi A, Kayaba K, Theorell T, Siegrist J. Association between job stress and depression among Japanese employees threatened by job loss in a comparison between two complementary job-stress models. Scand J Work Environ Health. 2001;27(2):146-53.

18. Parslow R, Jorm A, Christensen H, Broom D, Strazdins L, D'Souza R. The impact of employee level and work stress on mental health and GP service use: an analysis of a sample of Australian government employees. BMC Public Health. 2004;4:41.

19. Godin I, Kittel F. Differential economic stability and psychosocial stress at work: associations with psychosomatic complaints and absenteeism. Soc Sci Med. 2004;58:1543-53.

20. Sanne B, Mykletun A, Dahl A, Moen B, Tell G. Testing the job Demand-Control-Support model with anxiety and depression as outcomes: The Hordaland Health Study. Occup Med (Lond).
2005;55:463-73.

21. Laaksonen M, Rahkonen O, Martikainen P, Lahelma E. Associations of psychosocial working conditions with self-rated general health and mental health among municipal employees. Int Arch Occup Environ Health. 2006;79:205-12.

22. Kawakami N, Haratani T, Araki S. Effects of perceived job stress on depressive symptoms in blue-collar workers of an electrical factory in Japan. Scand J Work Environ Health. 1992;18:195-200.

23. Mino Y, Shigemi J, Tsuda T, Yasuda N, Bebbington P. Perceived job stress and mental health in precision machine workers of Japan: a 2 year cohort study. Occup Environ Med. 1999;56:41-5.

24. Shigemi J, Mino Y, Ohtsu T, Tsuda T. Effects of perceived job stress on mental health. A longitudinal survey in a Japanese electronics company. Eur J Epidemiol. 2000;16:371-6.

25. Bildt $\mathrm{C}$, Michelsen $\mathrm{H}$. Gender differences in the effects from working conditions on mental health: a 4-year follow-up. Int Arch Occup Environ Health. 2002;75:252-8.

26. De Lange AH, Taris TW, Kompier MAJ, Houtman ILD, Bongers PM. The relationships between work characteristics and mental health: Examining normal, reversed and reciprocal relationships in a 4-wave study. Work Stress. 2004;18:149 66.

27. Kawakami N, Araki S, Kawashima M. Effects of job stress on occurrence of major depression in japanese industry-a casecontrol study nested in a cohort study. J Occup Environ Med. 1990;32:722-5.

28. Niedhammer I, Goldberg M, Leclerc A, Bugel I, David S. Psychosocial factors at work and subsequent depressive symptoms in the Gazel cohort. Scand J Work Environ Health. 1998;24:197-205.

29. Carayon P. A longitudinal test of Karasek's job strain model among office workers. Work Stress. 1993;7:299-314.

30. Stansfeld S, Fuhrer R, Head J, Ferrie J, Shipley M. Work and psychiatric disorder in the Whitehall II study. J Psychosom Res. 1997;43:73-81.

31. Stansfeld S, Bosma H, Hemingway H, Marmot M. Psychosocial work characteristics and social support as predictors of SF-36 health functioning: The Whitehall II study. Psychosom Med. 1998;60:247-55.

32. Stansfeld S, Fuhrer R, Shipley M, Marmot M. Work characteristics predict psychiatric disorder: prospective results from the Whitehall II study. Occup Environ Med. 1999;56:302-7.

33. Griffin J, Fuhrer R, Stansfeld S, Marmot, M. The importance of low control at work and home on depression and anxiety: do these effects vary by gender and social class? Soc Sci Med. 2002;54:783-98.

34. Stansfeld S, Candy B. Psychosocial work environment and mental health - a meta-analytic review. Scand J Work Environ Health. 2006;32:443-62.

35. Bourbonnais R, Comeau M, Vezina M. Job strain and evolution of mental health among nurses. J Occup Health Psychol. 1999;4:95-107.

36. de Lange AH, Taris TW, Kompier MAJ, Houtman ILD, Bongers PM. Effects of stable and changing demand-control histories on worker health. Scand J Work Environ Health. 2002;28:94-108.

37. Godin I, Kittel F, Coppieters Y, Siegrist J. A prospective study of cumulative job stress in relation to mental health. BMC Public Health 2005;5:67.

38. Pelfrene E, Vlerick P, Kittel F, Mak R, Kornitzer M, De Backer G. Psychosocial work environment and psychological well-being: assessment of the buffering effects in the job de- 
mand-control(-support) model in BELSTRESS. Stress Health. 2002; 18:43-56.

39. Pelfrene E, Vlerick P, Moreau M, Mak R, Kornitzer M, De Backer G. Use of benzodiazepine drugs and perceived job stress in a cohort of working men and women in Belgium: results from the BELSTRESS-study. Soc Sci Med. 2004;59:43342.

40. De Bacquer D, Pelfrene E, Clays E, Mak R, Moreau M, de Smet P, et al. Perceived job stress and incidence of coronary events: three year follow-up of the BELSTRESS cohort. Am J Epidemiol. 2005; 161:434-41.

41. Moreau M, Valente F, Mak R, Pelfrene E, de Smet P, De Backer $\mathrm{G}$, et al. Occupational stress and incidence of sick leave in the Belgian workforce: the Belstress study. J Epidemiol Community Health. 2004;58:507-16.

42. Karasek R. Job content instrument: questionnaire and user's guide. Los Angeles (CA): University of Southern California; 1985.

43. Pelfrene E, Vlerick P, Mak R, De Smet P, De Backer G, Kornitzer M. Scale reliability and validity of the Karasek 'job demand-control-support' model in the Belstress-study. Work Stress. 2001;15:297-313.

44. Radloff L. The CES-D Scale: a self-report depression scale for research in the general population. Appl Psychol Meas. $1977 ; 1: 385-401$.

45. Kohout F, Berkman L, Evans D, Cornoni-Huntley J. Two shorter forms of the CES-D Depression Symptoms Index. J Aging Health. 1993;5:179-93.

46. Carpenter J, Andrykowski M, Wilson J, Hall L, Rayens M, Sachs B, et al. Psychometrics for two short forms of the center for epidemiologic studies-depression scale. Issues Ment Health Nurs. 1998;19:481-94.

47. Schwartzberg N, Dytell R. Dual-earner families: the importance of work stress and family stress for psychological well- being. J Occup Health Psychol. 1996;1:211-23.

48. Daniels K, Guppy A. Occupational stress, social support, job control, and psychological well-being. Hum Relat. 1994;47:1523-44.

49. Parkes K. Locus of control as moderator-an explanation for additive versus interactive findings in the demand-discretion model of work stress. Br J Psychol. 1991;82:291-312.

50. Berkman L, Syme S. Social networks, host-resistance, and mortality-9-year follow-up-study of Alameda County residents. Am J Epidemiol. 1979;109:186-204.

51. Sun G, Shook T, Kay G. Inappropriate use of bivariable analysis to screen risk factors for use in multivariable analysis. J Clin Epidemiol. 1996;49:907-16.

52. de Lange AH, Taris TW, Kompier MAJ, Houtman ILD, Bongers PM. "The very best of the millennium": longitudinal research and the Demand-Control-(Support) Model. J Occup Health Psychol. 2003;8:282-305.

53. Landsbergis P, Schnall P, Pickering T, Schwartz J. Validity and reliability of a work history questionnaire derived from the job content questionnaire. J Occup Environ Med. 2002;44:103747.

54. Kivimäki M, Head J, Ferrie J, Brunner E, Marmot M, Vahtera $\mathrm{J}$, et al. Why is evidence on job strain and coronary heart disease mixed? An illustration of measurement challenges in the Whitehall II Study. Psychosom Med. 2006;68:398-401.

55. Spector P. Method variance in organizational research. Organ Res Methods. 2006;9:221-32.

56. Tennant C. Work-related stress and depressive disorders. J Psychosom Res. 2001;51:697-704.

57. Cox T, Leka S, Ivanov I, Kortum E. Work, employment and mental health in Europe. Work Stress. 2004;18:179-85.

Received for publication: 2 June 2006 